\title{
The effect of increasing methionine supply on the methionine conversion to cyst(e)ine in sheep
}

\author{
BY P. M. PISULEWSKI* AND P. J. BUTTERY† \\ Department of Applied Biochemistry \& Food Science, University of Nottingham, \\ School of Agriculture, Sutton Bonington, Loughborough, Leicestershire LE12 5RD
}

(Received 20 July 1984 - Accepted 28 January 1985)

1. The conversion of methionine to cyst(e)ine was determined in sheep infused with different amounts of methionine $(0-5 \mathrm{~g} / \mathrm{d})$ into the duodenum by assaying the incorporation of ${ }^{35} \mathrm{~S}$ from intravenously-infused $\left.\mathrm{L}-{ }^{35} \mathrm{~S}\right]$ methionine into cyst(e)ine in wool, plasma albumin and the free plasma pool.

2. The percentage of cystine-S in the plasma originating from methionine increased linearly from 4.5 to 18 with increasing supplemental methionine supply.

3. The percentage of cysteine-S in albumin increased from 15 to 50 ; methionine supply increased to $3 \mathrm{~g} / \mathrm{d}$ but then remained constant, indicating that the transsulphuration pathway of the liver was exceeded.

4. The percentage of wool cysteine-S originating from methionine was high $(\sim 70)$ at all methionine supplementation rates.

There is considerable evidence that the supply to the duodenum of the sulphur-containing amino acids methionine and cystine can limit ruminant productivity. The two-phase dose-response relation between post-ruminal methionine supply and plasma free methionine concentration has frequently identified methionine as the first-limiting amino acid in both sheep (Chalupa \& Chandler, 1972; Reis et al. 1973; Strath \& Shelford, 1978) and cattle (Williams \& Smith, 1974; Fenderson \& Bergen, 1975; Mathers et al. 1979). These results, however, are appropriate only to the conditions used in each experiment and cannot be readily applied to other situations (Bergen, 1979; Mathers \& Miller, 1979).

It is recognized that knowledge of the whole-body amino acid metabolism can aid attempts to define amino acid allowances for farm animals (Mathers \& Miller, 1979; MacRae \& Reeds, 1980). For example, Gill \& Ulyatt (1979) have used studies of plasma amino acid kinetics to investigate whole-body methionine metabolism in sheep and similar studies have been conducted in cattle (Mathers \& Miller, 1983). However, no attempt was made in these studies to estimate the extent of conversion of methionine to cystine quantitatively.

The objective of the present experiment was to estimate quantitatively the conversion of methionine to cystine in sheep. The transsulphuration pathway of methionine catabolism produces cystine (Findelstein, 1970) and probably constitutes a major drain on methionine in sheep. Cystine is a main component amino acid of wool (Hogan, 1975). In the present studies, sheep were infused intravenously with $\mathrm{L}-\left[{ }^{35}\right.$ S]methionine and the plasma plateau specific activities of both methionine and cystine were measured. From this the proportion of cystine originating from methionine was calculated. Subsequently cystine flux was determined following intravenous infusion of $\mathrm{L}-\left[{ }^{35} \mathrm{~S}\right] \mathrm{cystine}$. The estimated proportion of cystine originating from methionine and the cystine flux were then used to calculate the extent of the conversion of methionine to cyst(e)ine.

The predominant sites of the transsulphuration pathway in sheep are the liver (Radcliffe \& Egan, 1978) and the skin (Downes et al. 1964). In an attempt to assess the contribution

\footnotetext{
* Present address: Department of Animal Nutrition, Institute of Animal Production, 32-083 Balice, Poland.

$\dagger$ For reprints.
} 
Table 1. The composition of the experimental diet $(\mathrm{g} / \mathrm{kg})$

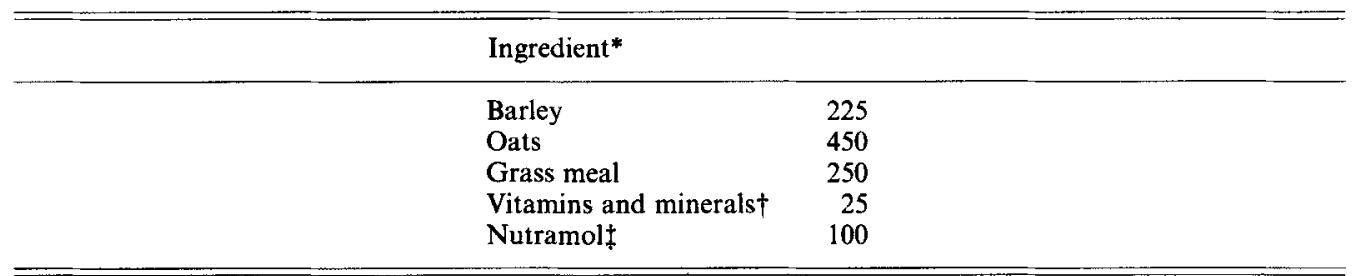

* Fresh weight basis.

$\dagger$ Wrightmin-Sheep (Frank Wright Ltd).

$\ddagger$ Molassed peat (Rumenco Ltd).

of these sites to whole-body methionine metabolism, the proportion of cystine originating from methionine was estimated in plasma albumin (synthesis is in the liver) and in wool samples.

The importance of methionine supply in limiting ruminant production is illustrated by the number of compounds investigated as potential derivatives (see, for example, Buttery et al. 1977). Some of these derivatives have been shown directly to increase methionine supply to the duodenum (Langar et al. 1978), but it is not known how much this extra methionine is being used to satisfy the cystine requirement of the animal. The possibility that the conversion of methionine to cysteine can be saturated under physiological or near physiological conditions was examined by studying the extent of the methionine conversion to cysteine as the supply of methionine to the duodenum was increased by infusion of L-methionine into the proximal duodenum.

\section{MATERIALS AND METHODS \\ Animals, diet and feeding}

Cross-bred wethers weighing approximately $30 \mathrm{~kg}$ were used. The sheep were fitted with single cannulas in the rumen and in the proximal duodenum 6 weeks before the start of the experiment. Throughout the experimental periods the animals were kept in metabolism crates at ambient temperatures and with continuous lighting. The composition of the experimental diet is shown in Table 1 . The diet was offered in equal portions at 2 -h intervals by an automatic feeder at a daily rate of $800 \mathrm{~g}$. Water was constantly available. The animals were adapted to the diet and the feeding regimen for $14 \mathrm{~d}$ before the start of the experimental period.

\section{Experimental design}

Six wethers were randomly allocated to six intraduodenal L-methionine infusion levels $(0$, $1,2,3,4$ and $5 \mathrm{~g} / 24 \mathrm{~h}$ ). Each infusion lasted the entire $10 \mathrm{~d}$ of the experimental period. L-Methionine (Sigma Chemical Co. Ltd, Poole, Dorset), dissolved in physiological saline $(9 \mathrm{~g}$ sodium chloride/l), was infused at a rate of $500 \mathrm{ml} / 24 \mathrm{~h}$.

\section{Collection and preparation of samples}

During the 10 d experimental period the samples of blood plasma, plasma albumin and wool were collected as indicated later (p. 123). On the 3rd day of the experimental period both jugular veins of each sheep were catheterized, one with a short $(150 \mathrm{~mm})$ and the other with a long $(250 \mathrm{~mm})$ catheter. The catheters were filled with sterile saline containing 250 units

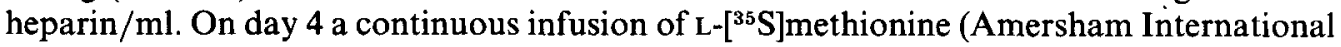


plc, Amersham, Bucks) was made via the long catheter while blood was sampled from the short one. The infusion solutions contained approximately $\left.1 \mathrm{mCi} \mathrm{L-}-{ }^{35} \mathrm{~S}\right] \mathrm{methionine}$ and $12.5 \mu \mathrm{mol} \mathrm{L}$-methionine in $250 \mathrm{ml}$ sterile saline and were infused at a rate of $20 \mathrm{ml} / \mathrm{h}$. Blood samples $(30 \mathrm{ml})$ were withdrawn into heparinized tubes at $0 \mathrm{~h}$ and then at $1,2,3,4,5,6$, 7 and $8 \mathrm{~h}$ after the beginning of the infusion. The catheters were flushed with heparinized saline after each sample. The whole-blood samples were immediately centrifuged at $2000 \mathrm{~g}$ for $15 \mathrm{~min}$ and the plasma obtained and stored in liquid nitrogen. The catheters were removed at the end of the methionine infusion. Both jugular veins were catheterized again on day 9 of the experimental period and on the following day the sheep were infused with $\mathrm{L}-\left[{ }^{35} \mathrm{~S}\right] \mathrm{cystine}$ (Amersham International plc). The infusion solutions contained approximately $1 \mathrm{mCi} \mathrm{L-}\left[{ }^{35} \mathrm{~S}\right]$ cystine and $12.5 \mu \mathrm{mol} \mathrm{L}$-cystine (Sigma Chemical Co. Ltd) in $250 \mathrm{ml}$ sterile saline and were infused at the same rate as $\mathrm{L}-\left[{ }^{35} \mathrm{~S}\right]$ methionine solutions. Blood samples were collected and prepared as described previously.

Plasma samples were deproteinized using the picric acid procedure of Stein \& Moore (1954). The deproteinized samples were then adjusted to $\mathrm{pH} 7$ with $1 \mathrm{~m}$-lithium hydroxide, cysteine oxidized to cystine, adjusted to $\mathrm{pH} 7$ with $1 \mathrm{M}$-hydrochloric acid and then stored at $-40^{\circ}$ (Stein \& Moore, 1954).

Separate samples of whole blood $(30 \mathrm{ml})$ were withdrawn during $\mathrm{L}-\left[{ }^{35} \mathrm{~S}\right] \mathrm{methionine}$ infusions at 6 and $8 \mathrm{~h}$ to isolate plasma albumin. The samples were immediately centrifuged as described previously and the plasma obtained stored in liquid $\mathrm{N}_{2}$. On thawing, plasma albumin was isolated according to the procedure of Swick \& Ip (1974). Following the final step of the procedure, albumin samples, dissolved in ethanol, were dried under vacuum for $24 \mathrm{~h}$ at $50^{\circ}$. The purity of albumin samples was confirmed using polyacrylamide gel electrophoresis (Laemmli, 1970). Bovine albumin (Sigma Chemical Co. Ltd) was used as a standard.

On the day preceding the $\mathrm{L}-\left[{ }^{35} \mathrm{~S}\right]$ methionine infusion, two $250 \times 250 \mathrm{~mm}$ mid-back patches of wool were clipped as closely as possible to the surface of the skin from each sheep. The clipped areas were kept covered until wool samples were collected $6 \mathrm{~d}$ later (the time taken for the radioactivity to appear above the skin surface (Downes, 1961)). The samples were washed with diethyl ether, ethanol and water and finally freeze-dried.

The samples of plasma albumin and wool were prepared using the performic acid procedure of Moore (1963) to oxidize sulphur amino acids to cysteic acid and methionine sulphone. Following oxidation the samples were hydrolysed with $6 \mathrm{M}-\mathrm{HCl}$ for $22 \mathrm{~h}$ at $110^{\circ}$. The hydrolysates were taken to dryness under reduced pressure, the residues redissolved in lithium citrate buffer ( $\mathrm{pH} \mathrm{2.2)}$, filtered through a $0.22 \mu \mathrm{m}$ filter (Millipore (UK) Ltd, Harrow) and stored at $-40^{\circ}$.

\section{Analytical techniques}

Feed samples were analysed for total $\mathbf{N}$ using the Kjeldahl procedure (Association of Official Agricultural Chemists, 1965). The deproteinized plasma samples and the hydrolysates (see above) of plasma albumin and wool were analysed for cystine and methionine or cysteic acid and methionine sulphone respectively, on an LKB 4400 (LKB Biochrom Ltd) amino acid analyser using lithium buffers. Amino acid concentrations were calculated with reference to DL-norleucine (BDH Ltd) as an internal standard.

The deproteinized plasma samples and the hydrolysates of plasma albumin and wool were assayed for ${ }^{35} \mathrm{~S}$ radioactivity in cystine and methionine or cysteic acid and methionine sulphone respectively. A preparative amino acid analyser operating on the lithium system of Atkin \& Ferdinand (1970) and a fraction collector were used to separate $S$ amino acids. The fractions of column effluent $(1.2 \mathrm{ml})$ were mixed with $10 \mathrm{ml}$ of a commercial scintillator solution (Fisofluor; Fisons Ltd, Loughborough) and counted on an Intertechnique SL 30 
Table 2. The effect of duodenal L-methionine infusion on plasma free methionine and cystine concentration in sheep

(The values are means with their standard errors of the nine samples taken during $\mathrm{L}-\left[{ }^{35} \mathrm{~S}\right] \mathrm{methionine}$ infusion)

\begin{tabular}{|c|c|c|c|c|c|}
\hline \multirow{2}{*}{$\begin{array}{l}\text { L-Methionine } \\
(\mathrm{g} / \mathrm{d})\end{array}$} & \multirow{2}{*}{$\begin{array}{c}\text { Infusion rate } \\
(\mu \mathrm{mol} / \mathrm{h})\end{array}$} & \multicolumn{2}{|c|}{$\begin{array}{l}\text { Plasma } \\
\text { methionine } \\
(\mu \mathrm{mol} / 1)\end{array}$} & \multicolumn{2}{|c|}{$\begin{array}{c}\text { Plasma } \\
\text { cystine } \\
(\mu \mathrm{mol} / 1)\end{array}$} \\
\hline & & Mean & $\mathbf{S E}$ & Mean & $\mathbf{S E}$ \\
\hline 0 & 0 & $2 \cdot 2$ & 0.4 & $4 \cdot 8$ & 0.2 \\
\hline 1 & 279 & 13.0 & 3.0 & $4 \cdot 0$ & 0.3 \\
\hline 2 & 558 & $19 \cdot 4$ & 0.9 & 3.8 & 0.2 \\
\hline 3 & 837 & $42 \cdot 0$ & $2 \cdot 4$ & $10 \cdot 7$ & 0.5 \\
\hline 4 & 1117 & 33.8 & $5 \cdot 3$ & $4 \cdot 7$ & 0.2 \\
\hline 5 & 1396 & 22.99 & $15 \cdot 2$ & 10.9 & 9.7 \\
\hline
\end{tabular}

scintillation counter. The external standard channels' ratio method was used to correct for quenching.

\section{Calculations}

The constant intravenous infusions of $\mathrm{L}-\left[{ }^{35} \mathrm{~S}\right]$ methionine and $\mathrm{L}-\left[{ }^{35} \mathrm{~S}\right]$ cystine were used to determine methionine and cystine flux respectively. The mean plasma plateau specific activities of methionine and cystine were calculated from the values obtained for plasma samples collected at 6,7 and $8 \mathrm{~h}$ after the beginning of the infusion. The flux was calculated by dividing the infusion rate of isotope by the plateau specific activity of methionine and cystine (Shipley \& Clark, 1972).

The proportion of cystine derived from methionine was calculated as the plateau specific activity ratio, cystine-S: methionine-S during the $L_{-}\left[{ }^{35} \mathrm{~S}\right]$ methionine infusion. This proportion and cystine flux during the $L-\left[{ }^{35} \mathrm{~S}\right]$ cystine infusion were used to calculate the amount of cystine synthesized from methionine. The amount of cystine synthesized from methionine was expressed on an equisulphur basis.

\section{RESULTS}

The plasma concentrations of methionine are presented in Table 2. A substantial increase in methionine concentration was noted when $5 \mathrm{~g} / \mathrm{d}$ were infused, indicating that methionine was exceeding requirements. The plasma cystine concentrations were not markedly affected by L-methionine infusions (Table 2).

The specific activities of plasma methionine and those of plasma cystine during L- $\left[{ }^{35} S\right]$ methionine infusions apparently reached plateau well before $6 \mathrm{~h}$. During L${ }^{[35}$ S]methionine infusions the maximum specific activity of plasma cystine recorded was $1.5 \times 10^{4}$ disintegrations/min per $\mu \mathrm{mol}$ cystine-S and this fell to background levels before $\mathrm{L}-\left[{ }^{35} \mathrm{~S}\right] \mathrm{cystine}$ infusions, when the plateau specific activities (reached before $6 \mathrm{~h}$ ) ranged from $5 \times 10^{4}$ to $1.25 \times 10^{5}$ disintegrations $/ \mathrm{min}$ per $\mu \mathrm{mol}$ cystine-S. Therefore it was assumed that carry-over effects on plasma cystine specific activity were minimal. Despite this it was considered unwise to attempt to use the same animal for several experimental periods (i.e. different duodenal methionine infusion rates), thus the replication of the experimental values was restricted.

The values of methionine and cystine flux through the plasma pool are presented in 
Table 3. The effect of L-methionine infusion on methionine and cystine flux, the percentage of cystine flux originating from methionine and the percentage of methionine flux converted to cystine in sheep, calculated from plasma free amino acid specific activities

\begin{tabular}{|c|c|c|c|c|c|c|c|c|}
\hline \multirow{2}{*}{\multicolumn{2}{|c|}{$\begin{array}{l}\text { L-Methionine } \\
\text { infusion level }\end{array}$}} & \multirow{2}{*}{$\begin{array}{c}\text { Methionine } \\
\text { flux } \\
(\mu \mathrm{mol} / \mathrm{h})\end{array}$} & \multirow{2}{*}{$\begin{array}{l}\text { Cystine- } \\
\text { sulphur } \\
\text { flux } \dagger \\
(\mu \mathrm{mol} / \mathrm{h})\end{array}$} & \multirow{2}{*}{$\begin{array}{l}\text { Percentage } \\
\text { of cystine-S } \\
\text { originating } \\
\text { from } \\
\text { methionine }\end{array}$} & \multirow{2}{*}{$\begin{array}{l}\text { Amount of } \\
\text { cystine-S } \\
\text { originating } \\
\text { from } \\
\text { methionine } \\
(\mu \mathrm{mol} / \mathrm{h})\end{array}$} & \multirow{2}{*}{$\begin{array}{l}\text { Percentage of } \\
\text { methionine } \\
\text { flux } \\
\text { converted to } \\
\text { cystine }\end{array}$} & \multicolumn{2}{|c|}{$\begin{array}{c}\text { Apparent whole-body } \\
\text { protein synthesis* } \\
\text { (g/kg body-weight }{ }^{0 \cdot 75} \\
\text { per d) }\end{array}$} \\
\hline & & & & & & & $\begin{array}{l}\text { Methionine } \\
\text { flux }\end{array}$ & $\begin{array}{l}\text { Cystine } \\
\text { flux }\end{array}$ \\
\hline 0 & 0 & 880 & 418 & $4 \cdot 51$ & 18.8 & $2 \cdot 13$ & $10 \cdot 69$ & 6.90 \\
\hline 1 & 279 & 1198 & 1154 & $5 \cdot 80$ & 66.9 & 5.58 & $14 \cdot 52$ & $19 \cdot 78$ \\
\hline 2 & 558 & 1070 & 930 & $8 \cdot 24$ & $76 \cdot 6$ & $7 \cdot 15$ & $9 \cdot 87$ & 12.09 \\
\hline 3 & 837 & 1362 & 676 & $13 \cdot 73$ & $92 \cdot 8$ & 6.81 & $17 \cdot 36$ & $12 \cdot 38$ \\
\hline 4 & 1117 & 1461 & 1306 & 13.04 & $170 \cdot 3$ & 11.65 & $19 \cdot 58$ & 24.82 \\
\hline 5 & 1396 & 2166 & 992 & $18 \cdot 53$ & 183.8 & $8 \cdot 48$ & $27 \cdot 61$ & $18 \cdot 20$ \\
\hline
\end{tabular}

* Calculated from the cysteine and methionine content of sheep muscle (Lawrie, 1974) but not corrected for total input of cystine or methionine from intestines or for oxidation of cystine or methionine as appropriate (see text).

$\dagger$ Calculated from plasma specific activity during $L-\left[{ }^{35} S\right]$ cystine infusion.

Table 3. The regression of methionine flux $(Y, \mu \mathrm{mol} / \mathrm{h}) v$. methionine infusion ( $X$, $\mu \mathrm{mol} / \mathrm{h}$ ) was as follows:

$$
Y=0.76(\text { SE } 0.18) X+819.8 \quad(r 0.89, P<0.05) .
$$

In contrast to the significant relation between methionine infusion and methionine flux, no apparent systematic changes in cystine flux could be detected $(P>0 \cdot 30)$. Surprisingly, in the studies of Williams \& Leng (1972) the abomasal infusion of $2.5 \mathrm{~g} / \mathrm{d}$ of DL-methionine increased the entry rate of cystine from $92 \mathrm{mg} / \mathrm{h}$ to $142 \mathrm{mg} / \mathrm{h}$.

Increasing methionine infusion (Table 3) resulted in an increase in the percentage of plasma cystine originating from methionine. The values would indicate that between 4.59 $(0 \mathrm{~g}$ infused $)$ and $18.5 \%$ ( $5 \mathrm{~g}$ infused) of cystine originated from methionine. However, the regression of the percentage of cystine originating from methionine $(Y, \%) v$. methionine infusion $(X, \mu \mathrm{mol} / \mathrm{h})$ was not significant:

$$
Y=0.006(\text { SE } 0.003) X+7.02 \quad(r 0.70, P>0.05) \text {. }
$$

The regressions of both the amount of cystine synthesized from methionine $(Y, \mu \mathrm{mol} / \mathrm{h})$ and the conversion of methionine to cystine $(Y, \%) v$. methionine infusion $(X, \mu \mathrm{mol} / \mathrm{h})$ were described by the following equations:

$$
\begin{aligned}
Y(\mu \mathrm{mol} / \mathrm{h}) & =0.478(\mathrm{SE} 0.015) X+19.30 \quad(r 0.96, P<0.01), \\
Y(\%) & =0.005(\mathrm{SE} \mathrm{0.001)} X+3.42 \quad(r 0.83, P<0.05) .
\end{aligned}
$$

It should be noted, however, that while increases in the amount of cyst(e)ine synthesized from methionine followed closely the increases in L-methionine infusion, the percentage of the methionine flux converted to cyst(e)ine did not show such a systematic change but was in the range of $2 \cdot 1-11 \cdot 6 \%$. Caution should be taken in extrapolating the plasma results presented in Table 3 to the whole animal since it would have to be assumed that plasma free amino acid pools equilibrate with the intracellular pools of amino acids, and this is not always the case (see Reeds \& Lobley, 1980). 
Table 4. The effect of L-methionine infusion on the percentage of cystine-sulphur originating from methionine in plasma albumin and wool

(Mean values with their standard errors of four determinations (two samples prepared and assayed in duplicate

\begin{tabular}{|c|c|c|c|c|c|}
\hline \multicolumn{2}{|c|}{$\begin{array}{l}\text { L-Methionine } \\
\text { infusion level }\end{array}$} & \multicolumn{2}{|c|}{ Albumin $(\%)$} & \multicolumn{2}{|c|}{ Wool $(\%)$} \\
\hline$(g / d)$ & $(\mu \mathrm{mol} / \mathrm{h})$ & Mean & SE & Mean & SE \\
\hline 0 & 0 & 14.81 & 0.94 & 67.23 & 1.67 \\
\hline 1 & 279 & 16.52 & 3.87 & & \\
\hline 2 & 558 & 42.66 & 2.82 & 65.99 & 1.66 \\
\hline 3 & 837 & 50.97 & 2.05 & 54.94 & 2.29 \\
\hline 4 & 1117 & $50 \cdot 10$ & $2 \cdot 82$ & & \\
\hline 5 & 1396 & $44 \cdot 56$ & 1.44 & $81 \cdot 59$ & $3 \cdot 28$ \\
\hline
\end{tabular}

* See below.

The percentage of cystine originating from methionine in the liver and the skin tissues, as indicated by plasma albumin and wool samples, was generally increased by L-methionine infusions (Table 4). However, the values for plasma albumin would indicate that, once this percentage reached the value of $40-50 \%(2-3 \mathrm{~g} \mathrm{~L}$-methionine infused/d), transsulphuration capacity of the liver had been exceeded. The values obtained for wool samples suggested generally higher transsulphuration capacity of the skin compared with the liver. In addition, the skin appeared to have adequate capacity to convert methionine to cystine even at the highest L-methionine infusion rates $(5 \mathrm{~g} / \mathrm{d})$. As only trace amounts of ${ }^{35} \mathrm{~S}$ radioactivity were present in wool samples collected from sheep infused with 1 and $4 \mathrm{~g}$ L-methionine, we have no explanation for this.

\section{DISCUSSION}

In the present study, plasma methionine concentration responded to the post-ruminal L-methionine infusions as expected. At least as indicated by changes in plasma methionine concentration (Table 2), the methionine status of the experimental animals varied from being deficient to being in excess.

The elevation in plasma methionine concentration in sheep infused with the $5 \mathrm{~g}$ L-methionine/d suggests that the apparent supplemental methionine requirement in the present study was between 4 and $5 \mathrm{~g} / \mathrm{d}$. This value was slightly higher than $3 \cdot 12 \mathrm{~g}$ (Chalupa \& Chandler, 1972), $3.3 \mathrm{~g}$ (Reis et al. 1973) or the value of $2.62 \mathrm{~g}$ (Strath \& Shelford, 1978) obtained in similar studies but with different diets. The changes in plasma methionine concentration may be compared with changes in methionine flux (Table 3). Methionine flux determined in the present study apparently responded to increasing L-methionine infusion rates, and the highest value of methionine flux was obtained at the highest rate of L-methionine infusion. The close resemblance between methionine duodenal supply and plasma methionine flux was previously reported in sheep (Fennessy et al. 1978; Gill \& Ulyatt, 1979) and in cattle (Mathers \& Miller, 1983).

In a simplified model of the whole-body amino acid metabolism (Garlick, 1980) the flux represents the rate at which an amino acid leaves the total free amino acid pool of the body by two ways: incorporation into protein and catabolism. This model has been used in studies on whole-body metabolism in sheep (Gill \& Ulyatt, 1979) and cattle (Mathers \& Miller, 1983). In the present studies, methionine flux was considered to represent the utilization 
for protein synthesis and for conversion of methionine to cystine. Interpretations of these findings are complicated by the possible increase in total body protein synthesis as methionine uptake increases. Some values are available for the oxidation rates of the carbon component of methionine.

The studies of Gill \& Ulyatt (1979) indicate that the percentage of methionine oxidized ranged from $13 \cdot 3$ to $19 \cdot 9$. It is also interesting to note that in calves infused with graded levels of methionine (Mathers \& Miller, 1983), methionine oxidation was increased from 17 to $30 \%$ over the range of methionine supplied. An estimate of methionine to cystine conversion was made in the present study. First the percentage of cystine flux originating from methionine was estimated over the experimental range of $L$-methionine infusion rates (Table 3). The substantial increase in this value $(4 \cdot 51-18.53 \%$ ) indicated increased catabolism of methionine via the transsulphuration pathway. In similar studies with steers (Buttery et al. 1984), the estimated percentage of cystine flux originating from methionine was 6.7 . The percentage of total methionine flux that was converted to cystine was calculated on an equisulphur basis from the amount of cystine synthesized daily from methionine and methionine flux values. The values obtained were in the range of $2 \cdot 13-11.65 \%$.

It is generally accepted that the conversion of methionine to cystine is particularly important in sheep (Armstrong \& Annison, 1973). As wool has high cystine and low methionine contents (Hogan, 1975), the absorbed methionine must be converted to cystine before incorporation into wool. The results obtained in the present study, both the proportion of cystine originating from methionine and methionine to cystine conversion, may suggest that the whole-body conversion of methionine to cystine is not efficient. As discussed by Reis et al. (1973) and also by Radcliffe \& Egan (1978), this inefficiency is also consistent with the plasma free methionine and cystine concentrations. In both studies post-ruminal methionine infusion resulted in high plasma methionine concentration while only slight changes in cystine concentration were observed. Plasma free methionine and cystine profiles obtained in the present study (Table 2) closely resembled those previously reported. It seems probable that the limited capacity of the liver to convert methionine to cystine (as discussed later) may be an important factor.

It has been assumed that whole-body protein synthesis can be calculated from an essential amino acid flux, provided the amino acid composition of body protein is known and the flux is corrected for dietary input or amino acid catabolism (Reeds \& Lobley, 1980). The apparent whole-body protein synthesis in the present study (Table 3) was calculated from methionine and cystine flux values assuming that the average methionine and cystine contents of sheep protein are $2 \cdot 3$ and $1 \cdot 3 \%$ respectively (Lawrie, 1974). Whole-body protein synthesis calculated from methionine flux without any correction for methionine catabolism or methionine uptake from the gut determined at the $0,1,2,3$ and $4 \mathrm{~g}$ infusion levels was in the range of $10-20 \mathrm{~g} / \mathrm{kg}$ body-weight $\mathrm{t}^{0.75}$ per $\mathrm{d}$. The values obtained may be compared with the values of 15.5 and $15.7 \mathrm{~g} / \mathrm{kg}$ body-weight ${ }^{0.75}$ per $\mathrm{d}$ reported for adult sheep by Bryant \& Smith (1982) and Reeds \& Lobley (1980) using tyrosine and leucine flux values respectively. The values calculated during the present study do give some confidence in the techniques used in the present study to measure plasma flux but also illustrate the need to correct flux rates before using them to assess whole-body protein synthesis. The apparent whole-body protein synthesis calculated for the sheep infused with the $5 \mathrm{~g} \mathrm{~L}$-methionine level was high $\left(27.6 \mathrm{~g} / \mathrm{kg}\right.$ body-weight ${ }^{0.75}$ per $\left.\mathrm{d}\right)$, presumably because of the increase in methionine availability. Food intake and presumably methionine leaving the abomasum remained constant. This increased flux was also observed in calves infused with increasing amounts of methionine (Mathers \& Miller, 1983).

We suggest that much of the variation in plasma cystine flux can largely be explained by technical difficulties in determining cystine specific activity. 
The survey studies on the distribution of the enzymes of methionine metabolism in ruminant tissues (Radcliffe \& Egan, 1974), clearly indicate that the methionine-cystine conversion pathway does not operate in skeletal muscle. This was confirmed using perfused ruminant diaphragm by Coward \& Buttery (1982). Radcliffe \& Egan (1978) studied hepatic enzymes of the transsulphuration pathway and implied that liver was the major site of methionine to cystine conversion. Downes et al. (1964), in studies on sheep, clearly demonstrated the activity of the transsulphuration pathway in the skin. As the liver and the skin are considered to be the main active sites of the transsulphuration pathway, the substantial proportion of cystine originating from methionine in plasma albumin and wool samples could be expected. The values obtained (Table 4) suggest that while the transsulphuration capacity of the liver was exceeded at the low duodenal L-methionine infusion rates $(2-3 \mathrm{~g})$ the transsulphuration capacity of the skin was not so easily exceeded. The limited transsulphuration capacity of the liver can be explained in terms of the metabolic regulation of methionine catabolism. It has been demonstrated (Radcliffe \& Egan, 1978 ) that the inability of the sheep to convert excessive amounts of methionine to cystine was associated with decreased activity of methionine adenosyltransferase $(E C 2.5 .1 .6)$ in the liver, resulting in reduced methionine entry into the transsulphuration pathway. The possibility of an alternative pathway of methionine catabolism also exists. As discussed by Steele \& Benevenga (1978), the transamination pathway of methionine metabolism may contribute significantly to methionine catabolism, especially when the capability of transsulphuration has been exceeded or impaired

It was shown (Downes et al. 1964) that after an intradermal dose of L- $\left[{ }^{35} \mathrm{~S}\right]$ methionine had been given, about $90 \%$ of the ${ }^{35} \mathrm{~S}$ incorporated into wool at the injection site was present as cystine. In addition, similar values of methionine and cystine as supplements for wool growth were demonstrated by Reis et al. (1973). The fact that the incorporation of ${ }^{35} \mathrm{~S}$ radioactivity into wool samples (the 1 and $4 \mathrm{~g}$-methionine infusion levels) could not always be measured is difficult to explain. As reported by Downes (1961), the specific activity of cystine in wool samples reached a maximum on the 6th day after an intravenous injection of DL- ${ }^{35}$ S $]$ cystine.

In conclusion, these findings show that while the methionine to cysteine conversion is active in sheep, the pathway in the liver can be easily saturated. The results again illustrate the compartmentalization of free amino acids within individual tissues and also suggest that the capacity of the skin to synthesize cystine from methionine is high.

The authors gratefully acknowledge the support of the Wellcome Foundation. They also would like to thank Mr D. Bozon, Miss C. Essex and Mr J. B. Soar for skilled technical assistance and Mrs J. Simpson for the care of the sheep.

\section{REFERENCES}

Armstrong, D. G. \& Annison, E. F. (1973). Proceedings of the Nutrition Society 32, 107-113.

Association of Official Agricultural Chemists (1965). Official Methods of Analysis of the Association of Official Agricultural Chemists, 10th ed. Washington, DC: Association of Official Agricultural Chemists.

Atkin, G. E. \& Ferdinand, W. (1970). Analytical Biochemistry 38, 313-329.

Bergen, W. G. (1979). Journal of Animal Science 49, 1577-1589.

Bryant, D. T. W. \& Smith, R. W. (1982). Journal of Agricultural Science, Cambridge 98, 639-643.

Buttery, P. J., Essex, C., Foulds, A. N. \& Soar, J. B. (1984). Proceedings of the Nutrition Society 43, 56A.

Buttery, P. J., Manomai-Udom, S. \& Lewis, D. (1977). Journal of the Science of Food and Agriculture 28, $481-485$.

Chalupa, W. \& Chandler, J. E. (1972). Tracer Studies on Non-Protein Nitrogen for Ruminants, pp 107-117. Vienna:

International Atomic Energy Agency.

Coward, B. J. \& Buttery, P. J. (1982). Journal of Agricultural Science, Cambridge 98, 307-316.

Downes, A. M. (1961). Australian Journal of Biological Science 14, 109-119.

Downes, A. M., Sharry, L. F. \& Till, A. R. (1964). Australian Journal of Biological Science 17, $945-959$.

Fenderson, C. L. \& Bergen, W. G. (1975). Journal of Animal Science 41, 1759-1766. 
Fennessy, P. F., Egan, A. R. \& Radcliffe, B. C. (1978). Proceedings of the Nutrition Society of Australia 3, 74.

Findelstein, J. D. (1970). In Sulphur in Nutrition, pp. 46-60 [O. H. Muth and J. E. Oldfield, editors], Westport: Avi Press.

Garlick, P. J. (1980). In Protein Deposition in Animals, pp. 51-67. [P. J. Buttery and D. B. Lindsay, editors]. London: Butterworths.

Gill, M. \& Ulyatt, M. J. (1979). British Journal of Nutrition 41, 605-609.

Hogan, J. P. (1975). Journal of Dairy Science 58, 1164-1177.

Laemmli, U. K. (1970). Nature 227, 680-685.

Langar, P. N., Buttery, P. J. \& Lewis, D. (1978). Journal of the Science of Food and Agriculture 29, $808-814$.

Lawrie, R. A. (1974). Meat Science, 2nd ed. Oxford: Pergamon Press.

MacRae, J. C. \& Reeds, P. J. (1980). In Protein Deposition in Animals, pp. 225-249 [P. J. Buttery and D. B. Lindsay, editors]. London: Butterworths.

Mathers, J. C. \& Miller, E. L. (1979). In Protein Metabolism in the Ruminant, pp. 3.1-3.11 [P. J. Buttery, editor]. London: Agricultural Research Council.

Mathers, J. C. \& Miller, E. L. (1983). In Proceedings of the 4th International Symposium on Protein Metabolism and Nutrition, pp. 29-32 [R. Pion, M. Arnal and D. Bonin, editors]. Paris: INRA.

Mathers, J. C., Miller, E. L. \& Lerman, P. M. (1979). Annales de Recherche Vétérinaires 10, 310-313.

Moore, S. (1963). Journal of Biological Chemistry 238, 235-237.

Radcliffe, B. C. \& Egan, A. R. (1974). Australian Journal of Biological Science 27, 465-471.

Radcliffe, B. C. \& Egan, A. R. (1978). Australian Journal of Biological Science 31, $105-114$.

Reeds, P. J. \& Lobley, G. E. (1980). Proceedings of the Nutrition Society 39, 43-52.

Reis, P. J., Tunks, D. A. \& Sharry, L. F. (1973). Australian Journal of Biological Science 26, $635-644$.

Shipley, R. A. \& Clark, R. E. (1972). Tracer Methods for In Vivo Kinetics. New York and London: Academic Press.

Steele, R. D. \& Benevenga, N. J. (1978). Journal of Biological Chemistry 235, 7844-7850.

Stein, W. H. \& Moore, S. (1954). Journal of Biological Chemistry 211, 915-926.

Strath, R. A. \& Shelford, J. A. (1978). Canadian Journal of Animal Science 58, 479-484.

Swick, R. W. \& Ip, M. M. (1974). Journal of Biological Chemistry, 249, 6836-6841.

Williams, A. J. \& Leng, R. A. (1972). Proceedings of the Australian Society of Animal Production 9, $326-330$.

Williams, A. P. \& Smith, R. H. (1974). British Journal of Nutrition 32, 421-433. 